\title{
Penilaian Tingkat Transparansi Musyawarah Perencanaan Pembangunan (Musrenbang) Kota Surabaya
}

\author{
Prima Tama Setyasa \\ Departemen Perencanaan Wilayah dan Kota, Fakultas Arsitektur, Desain, dan Perencanaan \\ Institut Teknologi Sepuluh Nopember (ITS) \\ Jl. Arief Rahman Hakim, Surabaya 60111 Indonesia \\ e-mail:psetyasa@gmail.com \\ Mahasiswa Departemen Perencanaan Wilayah dan Kota ITS
}

\begin{abstract}
Abstrak-E-musrenbang hadir dengan harapan dapat memenuhi perwujudan tata kelola pemerintahan yang baik (good governance). Dalam konsepsi good governance, transparansi publik menjadi sebuah prioritas tersendiri karena transparansi dapat memperkecil terjadinya kesalahan, sehingga masyarakat dapat turut menilai dan mengkritisi. Namun, dalam praktik musrenbang Kota Surabaya, masih terdapat temuan-temuan yang menuntun pada permasalahan transparansi kebijakan publik, diantaranya adalah elite capture, ketidaksesuaian data, dan hambatan-hambatan lain pada sistem. Hal seperti ini merupakan sebuah gap tersendiri mengingat Kota Surabaya juga bertindak sebagai kota prestatif dan percontohan bagi banyak wilayah lain di bidang kepemerintahan.

Hasil analisis menunjukkan bahwa dengan teknik analisis skoring Indeks Kepuasan Masyarakat, transparansi musrenbang Kota Surabaya dinilai baik, dengan klarifikasi transparansi variabel termasuk pada kategori baik dan sangat baik. Berdasarkan tipologi penilaian yang telah dilakukan sesuai klaster wilayah, Surabaya Selatan merupakan wilayah Surabaya dengan tingkat transparansi tertinggi dan mendapatkan label transparansi sangat baik (nilai indeks 83,365). Sedangkan Surabaya Barat merupakan wilayah Surabaya dengan tingkat transparansi terendah dan mendapatkan label transparansi baik (nilai indeks 74,881 ). Selain itu, diketahui pula bahwa variabel yang menjadi titik lemah pelaksanaan musrenbang Kota Surabaya saat ini adalah variabel "keterbukaan implementasi program".
\end{abstract}

Kata Kunci- good governance, musyawarah perencanaan pembangunan, transparansi

\section{PENDAHULUAN}

$\mathrm{P}$ ERENCANAAN merupakan bagian dasar dalam manajemen pembangunan [1]. Dengan adanya perencanaan diharapkan terdapatnya suatu pengarahan kegiatan, adanya pedoman bagi pelaksanaan bagi kegiatankegiatan yang ditujukan kepada pencapaian tujuan pembangunan [2]. Oleh karena itu, untuk dapat menjalankan suatu pembangunan yang baik, diperlukan suatu perencanaan yang matang, sehingga tujuan-tujuan yang hendak dicapai tersebut bisa dilaksanakan [1].

Semakin terbukanya ruang aspirasi dan partisipasi masyarakat semakin mendorong anggota masyarakat untuk dapat bergerak bersama dalam perencanaan pembangunan wilayahnya. Partisipasi merupakan berbagai corak tindakan massa maupun individual yang memperlihatkan adanya hubungan timbal balik antara pemerintah dengan warganya [3].
Pendekatan perencanaan tersebut sesuai dengan No. 25 Tahun 2004 Tentang Sistem Perencanaan Pembangunan Nasional dan terwujud dalam sebuah bentuk rangkaian musyawarah perencanaan pembangunan (musrenbang). Musrenbang adalah forum antarpelaku dalam rangka menyusun rencana pembangunan nasional dan pembangunan daerah, sehingga dilakukan secara berjenjang mulai dari tingkat desa, kecamatan, dan kabupaten/kota.

Seiring dengan perkembangan zaman dan teknologi, perlahan terjadi perubahan beberapa segmentasi kehidupan masyarakat, termasuk pada sistem musyawarah perencanaan pembangunan. Usulan pembangunan dari masyarakat tidak lagi dilakukan secara manual dan formal, tetapi telah difasilitasi oleh sistem aplikasi (online). E-musrenbang (electronic musrenbang) merupakan sebuah inovasi dalam sistem perencanaan pembangunan daerah dengan mengadopsi perkembangan teknologi, informasi, dan komunikasi [1]. Sebagaimana diungkapkan oleh Bapak Alvian selaku staf Bappeko Surabaya, munculnya electronic musrenbang (emusrenbang) ditandai dengan adanya permasalahan tentang banyaknya usulan yang masuk dalam bentuk cetak (hard copy), proses rekapitulasi yang lama, dan anggaran yang diberikan tidak tepat sasaran [4].

Pelaksanaan musrenbang pada dasarnya merupakan salah satu upaya untuk mewujudkan tata kelola pemerintahan yang baik (good governance). Prinsip-prinsip tersebut dalam konteks good governance terdiri atas legitimacy and voice (mencakup partisipasi dan berorientasi pada kesepakatan), direction (visi strategis), performance (tanggung jawab serta efektivitas dan efisensi), accountability (akuntabilitas dan transparansi), dan fairness (kepastian hukum dan keadilan) [5]. Transparansi memegang peranan penting dalam pelaksanaan e-musrenbang mengingat penerapan emusrenbang bertujuan untuk mempermudah warga untuk mendapatkan informasi tentang usulan yang telah dibahas di musrenbang [6]. Transparansi dan hak untuk mengakses informasi pemerintah saat ini telah diakui dunia sebagai unsur yang penting untuk partisipasi yang demokratis, kepercayaan kepada pemerintah, pencegahan korupsi, pembuatan keputusan, akurasi informasi publik, dan penyediaan informasi untuk masyarakat, pengusaha, serta jurnalis [7]. 
Surabaya merupakan salah satu daerah yang menerapkan musrenbang dengan sistem elektronik sebagai salah satu instrumen perencanaan pembangunannya. Surabaya menerapkan e-musrenbang mulai tahun 2009 [8], yang merupakan sistem yang mewajibkan pemerintah daerah untuk menyusun Rencana Kerja Perangkat Daerah (RKPD) yang berfungsi sebagai dokumen perencanaan daerah untuk periode satu tahun. Konsistensi pemerintah Kota Surabaya dalam mengembangkan sistem manajemen pemerintahan berbasis teknologi informasi ini bahkan telah mendapatkan respon positif dengan ditorehkannya beragam penghargaan, baik secara nasional maupun internasional. Hal ini menjadikan Kota Surabaya sebagai barometer penyelenggaraan pemerintah (best practice) berbasis elektronik (e-government) bagi daerah-daerah lain, termasuk halnya pada kasus musrenbang. Seperti diberitakan oleh humas.surabaya.go.id, sebanyak 17 kepala daerah melakukan penandatanganan kesepakatan kerja sama jaringan lintas perkotaan dengan Pemkot Surabaya [9].

Namun, sejak diterbitkannya Peraturan Menteri Dalam Negeri No. 86 Tahun 2017, terdapat peralihan sistem pelaksanaan musrenbang dari yang sebelumnya mengacu pada Peraturan Menteri Dalam Negeri No. 18 Tahun 2016. Perbedaan mendasar yang berlaku pada musrenbang Kota Surabaya salah satunya pada mekasnime pelaksanaannya. Pada pelaksanaan musrenbang tahun 2018, tingkatan paling dasar merupakan kegiatan rembuk warga yang dilaksanakan pada level kelurahan. Berbeda dengan musrenbang tahun sebelumnya yang berakar mulai dari tingkat RW (Rukun Warga). Dengan adanya perubahan tersebut, maka praktis penerapan musrenbang Kota Surabaya tahun 2018 dilangsungkan pada 4 tahapan.

Dengan demikian, penerapan dari musrenbang beserta sistem electroniknya tidak terlepas dari beberapa masalah. Meskipun telah memanfaatkan sistem online, pelaksanaan musrenbang masih dapat memiliki peluang terjadinya penyimpangan dalam perencanaan pembangunan. Elite capture sebagai suatu fenomena sosial masih dimungkinkan terjadi dalam setiap proses musrenbang. Dalam hal ini, elite capture dipahami sebagai suatu sikap atau tindakan yang dilakukan orang atau sekelompok orang untuk memengaruhi pembuatan kebijakan atau keputusan agar hasilnya memberikan keuntungan bagi mereka sendiri, baik yang berbentuk materi ataupun nonmateri [10]. Dalam konteks musrenbang ialah sekalipun usulan bersumber dari masyarakat pada rembuk kelurahan, tetapi yang memberikan validasi usulan ialah para pengambil keputusan pada tiga tahapan selanjutnya, yakni pemerintah kecamatan, SKPD, serta pemkot dan legislatif. Dengan kata lain, terdapat indikasi bahwa banyak usulan dari level kelurahan (yang diajukan oleh LPMK dan RW) tidak divalidasi, meskipun usulan tersebut sebenarnya sangat dibutuhkan masyarakat. Selain itu, ditemukan juga di lapangan bahwa masih terdapat beberapa usulan yang belum terlaksana dan tidak adanya feedback antara tingkatan musrenbang dengan dinas terkait [11].

Bagi Kota Surabaya, adanya penerapan $e$-musrenbang ini menjadi salah satu wadah dalam pencapaian prinsip good governance yang dikemukakan oleh United Nation Development Program (UNDP), diantaranya adalah transparansi. E-musrenbang mampu membuka ruang partisipasi yang luas kepada masyarakat dari segala tingkatan untuk memberikan aspirasi terkait pembangunan yang sesuai dengan kebutuhan masyarakat, sehingga memiliki posisi yang signifikan dalam pelaksanaan pembangunan bottom-up di Kota Surabaya. Seperti yang telah diuraikan di atas, peran Surabaya yang strategis sebagai wilayah percontohan mengharuskannya untuk selalu berbenah dan meningkatkan kualitas diri. Seiring dengan hal tersebut, temuan kendalakendala pada pelaksanaan musrenbang Kota Surabaya seyogyanya dapat menjadi sebuah pembelajaran dan pembenahan kebijakan publik yang lebih baik di masa mendatang.

Penelitian terkait penilaian transparansi musrenbang di Kota Surabaya diperlukan sebagai salah satu langkah awal dalam menilai keefektivan pelaksanaannya. Penilaian perlu dilakukan untuk mengetahui sejauh mana kualitas dari sebuah kebijakan secara keseluruhan, sebagai bentuk evaluasi dan untuk mendorong meningkatnya prestasi dari kebijakan tersebut. Seperti halnya dengan penelitian sebelumnya yang berhasil mendapati temuan ketidaksesuaian prinsip transparansi dalam good governance pada informasi publik salah satu kementerian [12], penelitian ini juga berfokus pada penilaian tingkat transparansi kebijakan publik. Kebijakan publik yang dimaksud adalah penerapan musrenbang yang disokong oleh sistem digital pada pelaksanaan tahun 2018 . Penelitian ini diharapkan dapat bermanfaat bagi masyarakat selaku subjek perencanaan pembangunan agar dapat memantau arah pembangunan kota secara lebih transparan, serta bagi Pemerintah Kota Surabaya sebagai pihak inisiator kebijakan (policy maker) agar dapat menerapkan prinsip tata kelola pemerintahan yang semakin baik ke depannya.

\section{METODE PENELITIAN}

\section{A. Pendekatan dan Jenis Penelitian}

Pendekatan yang digunakan dalam penelitian ini adalah pendekatan rasionalistik. Jenis penelitian dalam penelitian ini adalah campuran antara metode kualitatif dan kuantitatif.

\section{B. Variabel Penelitian}

Variabel penelitian yang digunakan untuk mengidentifikasi faktor-faktor berpengaruh terhadap transparansi musrenbang Kota Surabaya terdiri atas 10 atribut, yakni kejelasan prosedur, fasilitas media layanan, cara memperoleh data, kesesuaian substansi, hubungan antarlembaga, keterbukaan proses pelaksanaan, keterbukaan implementasi program, kejelasan informasi lainnya, sifat umum informasi, karakteristik khusus lainnya.

\section{Populasi dan Sampel Penelitian}

Sesuai dengan Peraturan Wali Kota Surabaya, diketahui bahwa seluruh warga Kota Surabaya berhak mengajukan usulannya pada setiap penyelenggaraan musrenbang, namun secara khusus terdapat 2 elemen masyarakat yang secara aktif mengusulkan, yakni pihak LPMK dan pihak RW. Dari populasi tersebut, penentuan ukuran sampel akan menggunakan rumus slovin dengan signifikansi 10\% maka: 
JURNAL PENATAAN RUANG Vol. 14, No. 1, (2019) ISSN: 2716-179X (1907-4972 Print)

$$
\mathrm{n}=\frac{N}{1+N \alpha^{2}}
$$

\section{Keterangan:}

$\mathrm{n}:$ Jumlah sampel

$\mathrm{N}:$ Jumlah populasi

$\alpha$ : Error Tolerance

Tabel 1.

Perhitungan Populasi Penelitian

\begin{tabular}{c|cc}
\hline Tipologi Populasi & $\begin{array}{c}\text { Jumlah Se-Surabaya } \\
(\text { Unit })\end{array}$ & $\begin{array}{c}\text { Jumlah Se-Surabaya } \\
(\text { Jiwa })\end{array}$ \\
\hline LPMK & 153 & 1.377 \\
RW & 1359 & 12.231 \\
Jumlah Populasi & & $\mathbf{1 3 . 6 0 8}$ \\
\hline
\end{tabular}

Sehingga,

$$
\begin{aligned}
& \mathrm{n}=\frac{13.608}{1+13.608(0,1)^{2}} \\
& \mathbf{n}=99,27 \sim \mathbf{9 9}
\end{aligned}
$$

Dan dengan perhitungan pecahan sederhana, maka diketahui bahwa dari 99 sampel di atas, 89 di antaranya wajib merupakan perwakilan RW, sedangkan 10 sisanya merupakan pewakilan LPMK (jumlah populasi LPMK jauh lebih sedikit daripada jumlah populasi RW).

Stratified random sampling berarti proses pengambilan sampel melalui proses pembagian populasi ke dalam strata [13]. Kota Surabaya yang tersekat secara administratif ke dalam 31 kecamatan yang berbeda, tentunya memiliki realisasi penyelenggaraan musrenbang yang berbeda-beda pula. Oleh sebab itu, 99 responden pada sasaran 2 perlu dibagi secara merata dan random ke 31 kecamatan tersebut, sehingga tiaptiap kecamatan memiliki jatah perwakilan sebanyak 3-4 responden. Dari 31 kecamatan di Kota Surabaya, terdapat 6 kecamatan dengan sampel 4 responden dan 25 kecamatan

\begin{tabular}{|c|c|c|}
\hline No. & $\begin{array}{c}\text { Jumlah Responden } \\
\text { (jiwa/kecamatan) }\end{array}$ & Penentuan Kecamatan \\
\hline 1. & 3 orang responden & $\begin{array}{l}\text { - Asemrowo } \\
\text { - Benowo } \\
\text { - Bubutan } \\
\text { - Bulak } \\
\text { - Dukuh Pakis } \\
\text { - Gayungan } \\
\text { - Genteng } \\
\text { - Gunung Anyar } \\
\text { - Jambangan } \\
\text { - Karangpilang } \\
\text { - Kenjeran } \\
\text { - Krembangan } \\
\text { - Lakarsantri } \\
\text { - Mulyorejo } \\
\text { - Pabean Cantian } \\
\text { - Pakal } \\
\text { - Sambikerep }\end{array}$ \\
\hline
\end{tabular}
dengan sampel 3 responden.

\begin{tabular}{|c|c|c|}
\hline No. & $\begin{array}{c}\text { Jumlah Responden } \\
\text { (jiwa/kecamatan) }\end{array}$ & Penentuan Kecamatan \\
\hline & & $\begin{array}{l}\text { - Semampir } \\
\text { - Simokerto } \\
\text { - Sukomanunggal } \\
\text { - Tandes } \\
\text { - Tegalsari } \\
\text { - Tenggilis Mejoyo } \\
\text { - Wiyung }\end{array}$ \\
\hline 2. & 4 orang responden & $\begin{array}{l}\text { - Tambaksari } \\
\text { - Sukolilo } \\
\text { - Rungkut } \\
\text { - Sawahan } \\
\text { - Gubeng } \\
\text { - Wonokromo }\end{array}$ \\
\hline
\end{tabular}

Tabel 2.
D. Menilai Tingkat Transparansi Pelaksanaan Musren-bang Kota Surabaya

Dalam menilai tingkat transparansi musrenbang Kota Surabaya, digunakan analisis skoring Indeks Kepuasan Masyarakat. Indeks kepuasan masyarakat digunakan untuk mengetahui bagaimana tanggapan masyarakat pengguna layanan ini terhadap pelayanan yang telah diberikan kepadanya [14].

Berikut ini merupakan beberapa tahapan perhitungan teknik skoring IKM:

1. Mengubah pilihan jawaban kuesioner dari huruf menjadi angka dengan cara: $\mathrm{a}=1 ; \mathrm{b}=2 ; \mathrm{c}=3$ dan $\mathrm{d}$ $=4$.

2. Menghitung Nilai Rata-rata Tiap Unsur (NR)

3. Menghitung terlebih dahulu Bobot Rata-rata Nilai Tertimbang

$$
\begin{gathered}
\text { Bobot Nilai Rata-rata Tertimbang }=\frac{\text { Jumlah Bobot }}{\text { Jumlah Unsur }} \\
\begin{array}{c}
\text { Bobot Nilai Rata-rata } \\
\text { Tertimbang }
\end{array}=\frac{1}{10}=\mathbf{0 , 1}
\end{gathered}
$$

4. Menghitung Nilai Rata-rata Tertimbang per Unsur = Nilai Rata-rata Tiap Unsur x 0,1

5. MenghitungIndeks Unit Pelayanan dengan menjumlahkan Nilai Rata-rata Tertimbang per Unsur

6. Mengonversikan Nilai Indeks Unit Pelayanan dengan mengalikannya dengan Nilai Dasar menjadi Nilai Konversi IKM (skala 25 - 100)

Nilai Konversi IKM = IKM Unit Pelayanan $\times 25$

7. Menghubungkan Nilai Konversi IKM (E) dengan standar berikut: 
Tabel 3.

Kategori Mutu Pelayanan IKM

\begin{tabular}{c|ccc}
\hline $\begin{array}{c}\text { Nilai Interval } \\
\text { IKM }\end{array}$ & $\begin{array}{c}\text { Nilai Interval } \\
\text { Konversi IKM }\end{array}$ & $\begin{array}{c}\text { Mutu } \\
\text { Pelayanan }\end{array}$ & $\begin{array}{c}\text { Kinerja Unit } \\
\text { Pelayanan }\end{array}$ \\
\hline $1,00-1,75$ & $25,00-43,75$ & $\mathrm{D}$ & Tidak Baik \\
$1,76-2,50$ & $43,76-62,50$ & $\mathrm{C}$ & Kurang Baik \\
$2,51-3,25$ & $62,51-81,25$ & $\mathrm{~B}$ & Baik \\
$3,26-4,00$ & $81,26-100,00$ & $\mathrm{~A}$ & Sangat Baik \\
\hline
\end{tabular}

\section{HASIL DAN DISKUSI}

\section{A. Tipologi Penilaian Tingkat Transparansi Pelaksanaan Musrenbang Kota Surabaya}

Adapun hasil perhitungan teknik skoring IKM terkait tingkat transparansi musrenbang Kota Surabaya adalah sebagai berikut:

Tabel 4.

Hasil Analisis Kategori Mutu Pelayanan IKM

\begin{tabular}{c|ccc}
\hline $\begin{array}{c}\text { Nilai Interval } \\
\text { IKM }\end{array}$ & $\begin{array}{c}\text { Nilai Interval } \\
\text { Konversi IKM }\end{array}$ & $\begin{array}{c}\text { Mutu } \\
\text { Pelayanan }\end{array}$ & $\begin{array}{c}\text { Kinerja Unit } \\
\text { Pelayanan }\end{array}$ \\
\hline $1,00-1,75$ & $25,00-43,75$ & D & Tidak Baik \\
$1,76-2,50$ & $43,76-62,50$ & C & Kurang Baik \\
$\mathbf{2 , 5 1}-\mathbf{3 , 2 5}$ & $\mathbf{6 2 , 5 1 - 8 1 , 2 5}$ & B & Baik \\
$3,26-4,00$ & $81,26-100,00$ & A & Sangat Baik \\
\hline
\end{tabular}

Berdasarkan hasil rekapitulasi data kuesioner dan analisis skoring Indeks Kepuasan Masyarakat, didapatkan sebuah assessment "Baik" pada tingkat transparansi musyawarah perencanaan pembangunan Kota Surabaya (dengan nilai 79,87). Dengan didasari oleh 10 variabel dan 23 kriteria, penilaian masyarakat terhadap transparansi pelayanan musrenbang Kota Surabaya berujung pada mutu pelayanan tingkat dua dari total empat level, yakni pada huruf "B".

Namun, baiknya tingkat transparansi pelaksanaan musrenbang Kota Surabaya ini nyatanya tidak disumbangkan oleh masing-masing variabel (unsur pelayanan) sama besarnya. Pada hasil pengolahan data, terdapat distribusi nilai yang cukup berbeda antarvariabelnya. Berikut ini merupakan hasil tabulasi penilaian tiap-tiap variabel penelitian:

Tabel 5. Hasil Perhitungan Skoring IKM Per Variabel

\begin{tabular}{|c|c|c|c|}
\hline No. & Unsur Pelayanan & $\begin{array}{c}\text { Nilai Unsur } \\
\text { Pelayanan } \\
\left(\mathbf{A}^{*}\right)\end{array}$ & $\begin{array}{l}\text { Kualitas } \\
\text { Pelayanan }\end{array}$ \\
\hline 1. & Kejelasan Prosedur & 3,495 & Sangat Baik \\
\hline 2. & Fasilitas Media Layanan & 3,162 & Baik \\
\hline 3. & Cara Memperoleh Data & 3,192 & Baik \\
\hline 4. & Kesesuaian Substansi & 3,141 & Baik \\
\hline 5. & Hubungan Antarlembaga & 3,121 & Baik \\
\hline 6. & $\begin{array}{l}\text { Keterbukaan Proses } \\
\text { Pelayanan }\end{array}$ & 3,293 & Sangat Baik \\
\hline 7. & $\begin{array}{l}\text { Keterbukaan } \\
\text { Implementasi Program }\end{array}$ & 2,980 & Baik \\
\hline 8. & $\begin{array}{l}\text { Kejelasan Informasi } \\
\text { Lainnya }\end{array}$ & 3,131 & Baik \\
\hline 9. & Sifat Umum Informasi & 3,242 & Baik \\
\hline 10. & $\begin{array}{l}\text { Karakteristik Khusus } \\
\text { Lainnya }\end{array}$ & 3,192 & Baik \\
\hline
\end{tabular}

Pada tabel di atas, diketahui bahwa kualitas pelayanan musrenbang Kota Surabaya dari sisi transparansinya mendapatkan hasil yang memuaskan. Terdapat dua penilaian yang sama-sama menunjukkan hasil yang positif, yakni penilaian "baik" dan penilaian "sangat baik".

Hampir seluruh variabel mendapatkan penilaian baik, yakni sebanyak 8 variabel. Kedelapan variabel tersebut adalah variabel fasilitas media layanan yang berkriteria ketersediaan fasilitas database dan prosedur pengaduan kepada pemerintah,

variabel kesesuaian substansi, variabel hubungan antarlembaga dengan satu-satunya kriteria yakni berlakunya prinsip check and balance antara lembaga eksekutif dan legislatif, variabel keterbukaan implementasi program dengan 3 kriteria di dalamnya, variabel kejelasan informasi lainnya, variabel sifat umum informasi yang berkriteria bersifat mudah dipahami, bersifat terbuka, bersifat akurat, lengkap, dan memadai, serta variabel karakteristik khusus lainnya yang terdiri atas kriteria bersifat partisipatif dan bersifat inklusif.

Pepatah di atas langit masih ada langit rupanya berlaku pada hasil skoring ini. Penilaian "sangat baik" berhasil disematkan kepada variabel ke-1 dan ke-6, yang berturut-turut yakni variabel kejelasan prosedur dan variabel keterbukaan proses pelayanan. Variabel kejelasan prosedur yang terdiri atas 3 kriteria itu merupakan variabel dengan torehan nilai rata-rata tertinggi dengan skor 3,495. Sedangkan variabel keterbukaan proses pelayanan menempati posisi kedua dengan nilai 3,293.

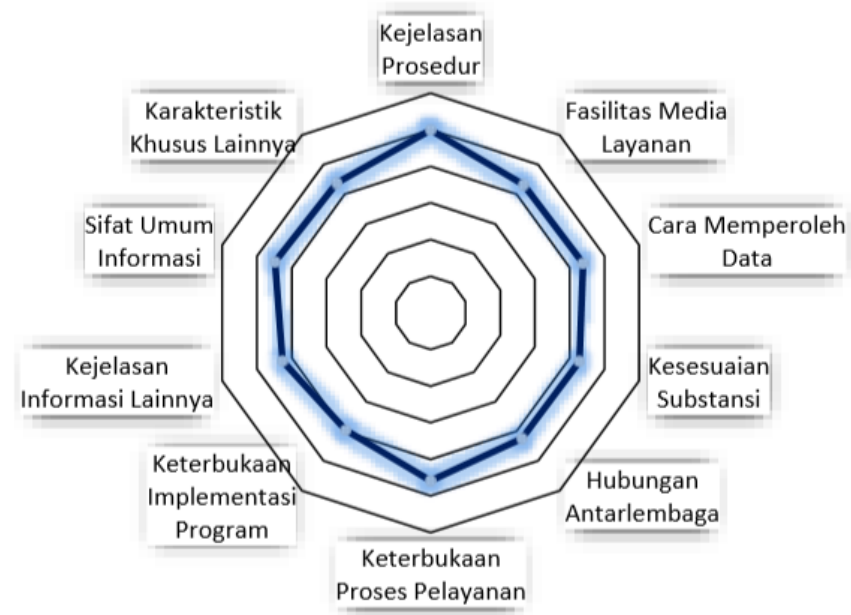

Gambar 1. Diagram Radar Kekuatan Transparansi per Variabel

Berdasarkan ilustrasi di atas, dapat terlihat secara lebih spesifik dan visual bahwa tingkat transparansi musrenbang Kota Surabaya dapat disebut tinggi. Hal ini terbukti dengan menggunakan skala radar $1-4$, poin-poin variabel penelitian (garis berwarna biru) berhasil menempati bagian luar dari diagram berbentuk segi sepuluh tersebut (semakin besar bentuk yang dihasilkan). Ini menandakan bahwa kekuatan masing-masing unsur pembentuknya (variabel penelitian) tinggi.

Sesuai dengan hasil analisis secara holistik, tingkat transparansi musrenbang Kota Surabaya adalah "baik", yaitu dengan nilai 79,87 dari nilai maksimal 100. Hal yang sama berlaku pada penilaian masing-masing variabelnya yang berujung pada konklusi penilaian "baik" dan "sangat baik". Berikut adalah beberapa unsur pelayanan yang disusun dari kualitas terbaik hingga yang terburuk: 


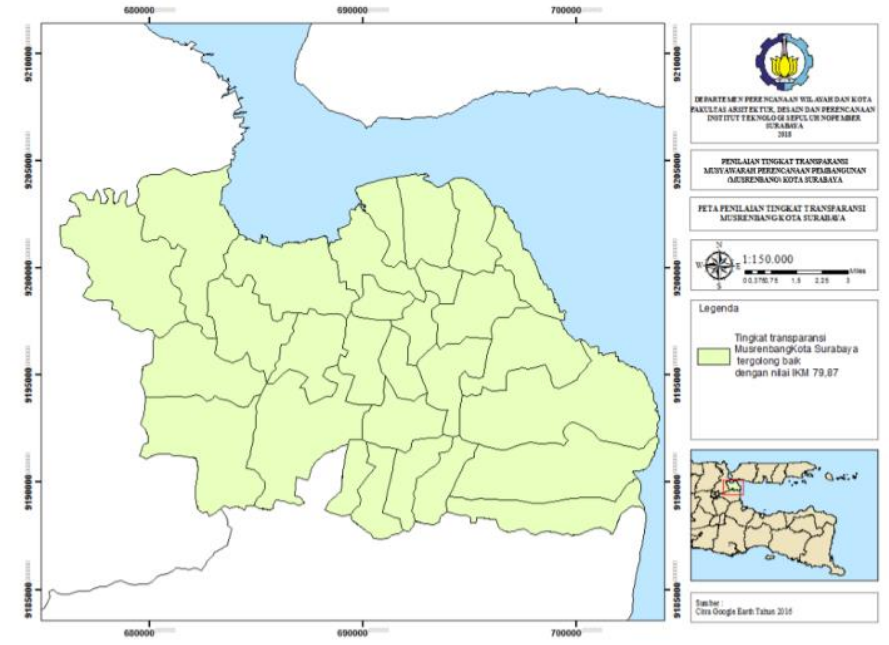

Gambar 2. Peta Penilaian Tingkat Transparansi Musrenbang Kota Surabaya

Setelah diketahui penilaian tingkat transparansi pada level Kota secara umum, penilaian tingkat transparansi musrenbang juga dapat ditopologikan berdasarkan klaster kewilayahannya. Keuntungan dari perlakuan ini adalah didapatkannya bentuk penilaian yang lebih spesifik pada wilayah studi dengan cara mengakomodasi pelaksanaan musrenbang berdasarkan kedekatan/pelingkupan wilayahnya.

Terdapat 5 pembagian klaster wilayah Kota Surabaya yang dibahas pada hasil analisis penelitian ini, yakni Surabaya Pusat, Surabaya Timur, Surabaya Utara, Surabaya Selatan, dan Surabaya Barat.

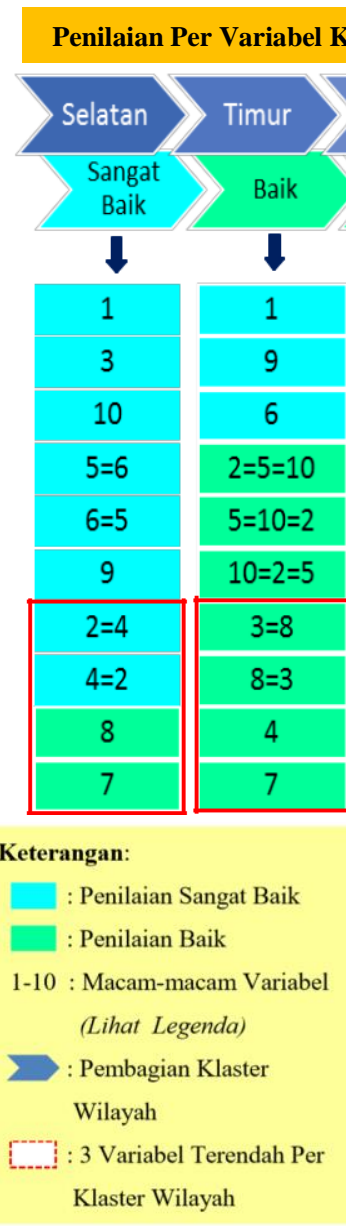

Gambar 3. Penilaian Tingkat Transparansi per Variabel Klaster Wilayah Surabaya

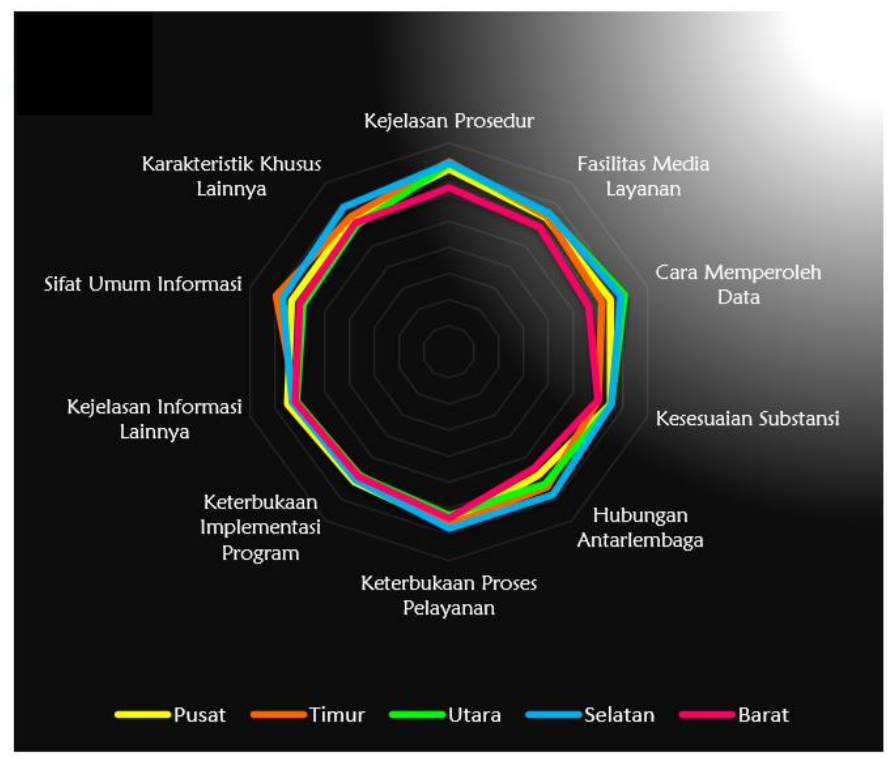

Gambar 4. Perbandingan Penilaian Tingkat Transparansi per Variabel Klaster Wilayah Kota Surabaya

Melalui tipologi penilaian musrenbang di atas, terdapat beberapa temuan menarik yang bisa dijadikan sebagai input yang baik bagi pembenahan pelaksanaan musrenbang ke depannya. Temuan-temuan tersebut diantaranya adalah:

a. Kualitas musrenbang terbaik ada pada klaster wilayah Selatan Surabaya. Bahkan penilaian yang diraih oleh Surabaya Selatan berhasil melampaui angka 81,25 (tepatnya 83,365) yang berarti berada pada kriteria sangat baik. Hal ini merupakan sebuah pencapaian tersendiri lantaran nilai ini jauh meninggalkan bagian Surabaya lainnya, dan bahkan juga di atas rata-rata penilaian musrenbang Kota Surabaya secara holistik.

b. Tingginya nilai yang digapai oleh klaster Surabaya Selatan tak dapat dipungkiri juga ditopang oleh nilai tiap variabelnya yang juga tinggi. Tercatat, dari 10 variabel, 8 diantaranya mendapatkan assessment sangat baik. Sedangkan sisanya, yakni variabel "keterbukaan implementasi program" dan "kejelasan informasi lainnya" mendapatkan "hanya" assessment baik.

c. Surabaya Timur merupakan klaster wilayah dengan tingkat transparansi musrenbang terbaik kedua setelah bagian Selatan, yakni dengan perolehan 80,3 (baik). Keberhasilan ini tak lepas dari kontribusi variabel "kejelasan prosedur", "sifat umum informasi", dan " keterbukaan proses pelayanan" yang mendapatkan penilaian sangat baik. Di sisi lain, variabel dengan nilai terendah pada kasus Surabaya Timur adalah variabel "cara memperoleh data" dan "kejelasan informasi lainnya" dengan nilai yang sama, "kesesuaian substansi", dan "keterbukaan implementasi program".

d. Pelaksanaan musrenbang di empat kecamatan Surabaya Pusat memperoleh penilaian baik dengan angka kumulatif 80,208. Hampir sama dengan Surabaya Timur, terdapat dua variabel transparansi yang mendapatkan nilai sangat tinggi (sangat baik), dan sisanya adalah baik. Hal menarik pada kasus Surabaya pusat ini adalah 3 variabel dengan nilai terendah ternyata ditorehkan oleh 5 
JURNAL PENATAAN RUANG Vol. 14, No. 1, (2019) ISSN: 2716-179X (1907-4972 Print)

variabel yang berbeda, yakni fasilitas media layanan", "sifat umum informasi", "karakteritik khusus lainnya","keterbukaan implementasi program", dan " hubungan antralembaga",

e. Surabaya Utara merupakan region Surabaya dengan tingkat transparansi musrenbang terbaik keempat (dengan penilaian baik), namun nilai per variabelnya banyak yang tinggi. Meskipun 4 variabel berhasil menggaet label sangat baik, dan bahkan mampu mengalahkan perolehan Surabaya Timur (3 variabel sangat baik) dan Surabaya Pusat (2 variabel sangat baik), nilai rata-rata seluruh variabel mengalami antiklimaks. Hal ini terjadi lantaran adanya kesenjangan yang cukup besar antara variabel tertinggi dengan variabel terendahnya, yakni sebesar 0,667.

f. Surabaya Barat merupakan bagian Kota Surabaya dengan pelaksanaan musrenbang paling tidak baik secara keseluruhan, meskipun penilaian transparansinya menyatakan baik. Seluruh variabel transparansi musrenbang di Surabaya Baratpun mendapatkan assessment baik. Dengan angka 74,881, pelaksanaan musrenbang di bagian Kota Surabaya dengan 7 kecamatan ini terbilang berada di bawah rata-rata keseluruhan penialaian pelaksanaan di Kota Surabaya.

g. Secara akumulatif, variabel 1, yakni variabel "kejelasan prosedur", merupakan variabel yang selalu menempati variabel terbaik (pertama) di seluruh bagian wilayah Surabaya.

h. Sebaliknya, variabel 7, yakni variabel "keterbukaan implementasi program" rupanya akan menjadi fokus utama pemkot Surabaya ke depannya. Variabel ini merupakan "momok" serius bagi transparansi musrenbang di seluruh bagian Kota Surabaya, bahkan di Surabaya Selatan sekalipun. Variabel ini berturutturut menjadi variabel terburuk di Surabaya Selatan, Surabaya Timur, Surabaya Utara, terburuk kedua di Surabaya Pusat, dan terburuk ketiga di Surabaya Barat.

i. Selain variabel "keterbukaan implementasi program" variabel lain yang hampir ada di seluruh 3 besar terendah per klaster wilayah adalah variabel "fasilitas media layanan" dengan 3 kemunculan pada Surabaya Selatan, Surabaya Pusat, dan Surabaya Barat.

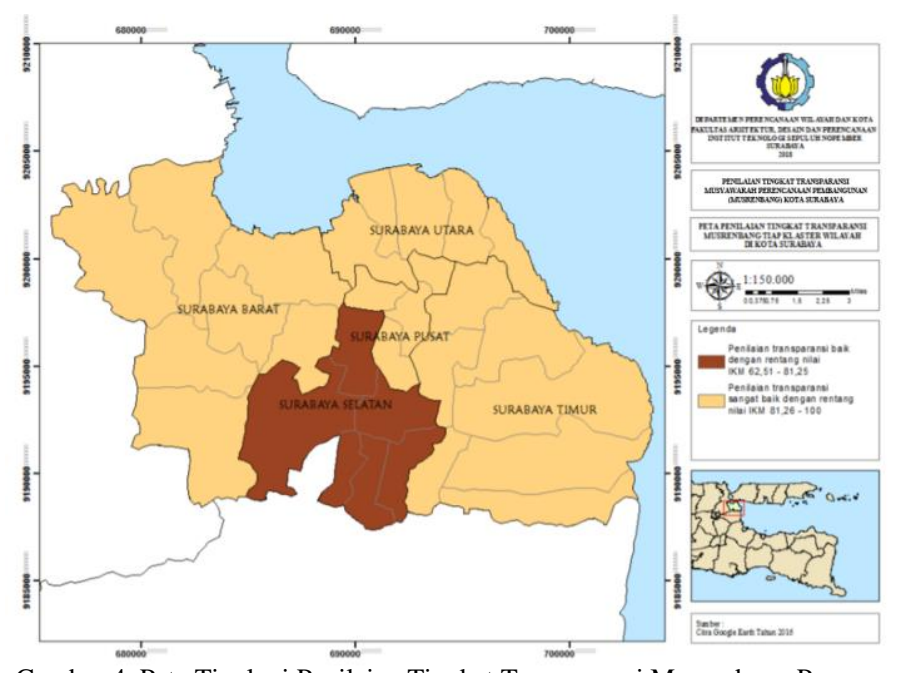

Gambar 4. Peta Tipologi Penilaian Tingkat Transparansi Musrenbang Per Klaster Wilayah Kota Surabaya

\section{KESIMPULAN}

\subsection{Kesimpulan}

Penelitian ini pada dasarnya bertujuan untuk melakukan penilaian terhadap transparansi musyawarah perencanaan pembangunan yang dilakukan oleh penduduk Kota Surabaya itu sendiri. Berdasarkan analisis yang telah dilakukan, diperoleh beberapa kesimpulan sebagai berikut:

a. Musyawarah perencanaan pembangunan Kota Surabaya dinilai berdasarkan pelaksanaannya secara makro, kinerja per variabelnya, pelaksanaannya secara lebih mikro tiap-tiap klaster wilayah, dan kinerja per variabel pada tipologi per klaster wilayah.

i.) Pelaksanaan musyawarah perencanaan pembangunan Kota Surabaya dinilai "baik" oleh masyarakat dari sisi transparansinya. Dengan didasari oleh 10 variabel dan 23 kriteria, penilaian masyarakat tersebut berujung pada mutu pelayanan tingkat dua dari total empat level, yakni pada huruf "B".

ii.) Hal yang sama berlaku pada penilaian masingmasing variabelnya yang bermuara pada konklusi penilaian "baik" dan "sangat baik". Sebanyak 8 variabel yang terdiri atas 18 kriteria mendapatkan assessment "baik", sedangkan sisanya (2 variabel dengan 5 kriteria) berhasil mencapai range nilai tertinggi dan memperoleh indikasi "sangat baik".

iii.) Dipandang dari kualitas tranparansinya per klaster (bagian) wilayah Kota Surabaya, posisi yang terbaik hingga terburuk secara berturutturut ditempati oleh Surabaya Selatan, Surabaya Timur, Surabaya Pusat, Surabaya Utara, dan Surabaya Barat. Penilaian musrenbang di Surabaya Selatan berhasil mencapai "Sangat Baik", sedangkan keempat region sisanya meraih label "Baik".

iv.) Berdasarkan tipologi penilaian masing-masing klaster wilayah, diketahui bahwa variabel "Kejelasan Prosedur" merupakan variabel terbaik dan menjadi faktor utama di balik tingginya penilaian transparansi musrenbang di Kota Surabaya. Sebaliknya, dari 10 variabel yang ada, didapatkan 1 variabel yang merupakan faktor utama yang menghambat penyelenggaraan transparansi musrenbang Kota Surabaya. Variabel tersebut ialah variabel "Keterbukaan Implementasi Program" yang terdiri atas 2 kriteria.

\subsection{Rekomendasi}

Berdasarkan keseluruhan hasil penelitian yang telah dilakukan, terdapat beberapa rekomendasi yang disarankan oleh peneliti, sebagaimana berikut ini:

a. Melakukan penelitian pada wilayah lain untuk mereplikasi keberhasilan transparansi musrenbang di Kota Surabaya berdasarkan benchmarking karakteristik musrenbang Surabaya 
JURNAL PENATAAN RUANG Vol. 14, No. 1, (2019) ISSN: 2716-179X (1907-4972 Print)

b. Menjadikan penelitian ini sebagai masukan dalam peningkatan kualitas pelaksanaan musyawarah perencanaan pembangunan di Kota Surabaya. Terlebih, sebagai kota percontohan di bidang pemerintahan, evaluasi dan perbaikan kualitas merupakan suatu kebutuhan.

i.) Berdasarkan poin transparansinya, fokus perbaikan dan peningkatan kualitas transparansi musrenbang Kota Surabaya perlu memprioritaskan 3 hal utama, yakni keterbukaan implementasi programnya terlebih dahulu, kemudian hubungan antarlembaganya, dan selanjutnya kejelasan informasinya. Ketiga hal ini merupakan titik lemah pelaksanan musrenbang saat ini, dan perlu ditingkatkan secepatnya di pelaksaanaan berikutnya.

ii.) Berdasarkan persebaran pelaksanaannya, fokus perbaikan dan peningkatan kualitas transparansi musrenbang Kota Surabaya perlu diprioritaskan secara berturut-turut di Surabaya bagian Barat terlebih dahulu, lalu Surabaya Utara, kemudian Pusat Surabaya, selanjutnya Surabaya sebelah Timur, dan terakhir adalah Surabaya Selatan. Surabaya Barat dan Utara merupakan klaster wilayah dengan pelaksanaan musrenbang terburuk tahun ini, dan pemerataan kualitas transparansi perlu segera diupayakan. Pemilahan prioritas penanganan dan adanya transfer ilmu dari Surabaya Selatan merupakan salah satu langkah yang bisa diambil dalam upaya pemerataan kualitas transparansi pelaksanaan musrenbang Kota Surabaya.

\section{DAFTAR PUSTAKA}

[1] Yunas, Novy Setia. 2017. Efektivitas Musrenbang di Kota Surabaya dalam Sistem Perencanan Pembangunan Berparadigma Masyarkat. Surabaya. Research Gate

[2] Rustan. 2019. Pusara Pembangunan Ekonomi. Makassar. CV Sah Media.

[3] Kumorotomo, Wahyudi. 1999. Etika Administrasi Negara. Jakarta. PT Raja Grafindo Persada.

[4] Karuniawati, Reny Dwi. Fanida, Eva Hany. Efektivitas Sistem Electronic Musyawarah Rencana Pembangunan (Musrenbang) di Kecamatan Tambaksari Kota Surabaya. Surabaya. Universitas Negeri Surabaya

[5] Graham, John. Amos, Bruce. Plumptre, Tim. 2003. Principles for Good Governance in the $21^{\text {st }}$ Century. Ottawa. Institute On Governance.

[6] Azhar Fikri. 2015. Partisipasi Masyarakat dalam Musyawarah Perencanaan Pembangunan (MUSRENBANG) di Kelurahan Pegirian Kecamatan Semampir Kota Surabaya. Surabaya. Kebijakan dan Manajemen Publik ISSN 2303-341X Volume 3 Nomor 2.

[7] Kanter, Christopel Herman. Purnama, Asriani. 2015. Peran Website Pemerintah Kota Manado dalam Mendukung Terwujudnya Good Governance. Manado. Jurnal Penelitian Komunikasi dan Opini Publik Vol. 19 No. 3.

[8] Anonim. http://bappeko.surabaya.go.id/musrenbang2017 diakses pada tanggal 22 dan 27 November 2017

[9] Domi Wimpi. 2017. Pemkot Surabaya Kerja Sama Jaringan Lintas Perkotaan dengan 17 Kabupaten/Kota. https://humas.surabaya.go.id/2017/05/31/pemkot-surabaya-kerja-samajaringan-lintas-perkotaan-dengan-17-kabupatenkota/ diakses pada tanggal 19 Maret 2020
[10] Setiadi, dkk. 2016. Mengikis Elite Capture dalam Community Development: Pembelajaran dai bumi Seribu Nyiur Melambai. https://cpps.ugm.ac.id/publication/-mengikis-elite-capture-dalamcommunity-development-pembelajaran-dari-bumi-ser ibu-nyiurmelambai/ diakses pada tanggal 24 Juni 2018

[11] Putri, Nindia Prischa. 2015. Studi Eksplorasi Tentang Variabel Pendukung Keberhasilan Aplikasi Sistem Musrenbang di Bappeko Surabaya. Surabaya. Kebijakan dan Manajemen Publik Volume 3 Nomor 3

[12] Rahadian, Adinda Permatasari. Analisis Implementasi Kenijakan Tentang Keterbukaan Informasi Publik Studi Kasus pada Kementerian Pertanian, Jakarta.

[13] Demokrawati, Fiqa Adha. 2014. Analisis Quick Count dengan Menggunakan Metode Stratified Random Sampling (Studi Kasus Pemilu Walikota Bandung 2013). Bandung. Universitas Pendidikan Indonesia.

[14] Mote, Frederik. 2008. Analisis Indeks Kepuasan Masyarakat (IKM) Terhadap Pelayanan Publik di Puskesmas Ngesrep Semarang. Semarang. Universitas Diponegoro. 